\title{
Socio-Cultural Values of Selimbur Caye Oral Tradition in Pasemah Ethnic Bengkulu
}

\author{
Een Syaputra ${ }^{1}$, Sariyatun ${ }^{1}$, Sunardi $^{1}$ \\ ${ }^{1}$ Post-Graduate Program of History Education Sebelas Maret University, Surakarta, Indonesia. \\ email: yung_een@yahoo.co.id
}

\begin{abstract}
This article aimed to: 1) describe the content and meaning of Selimbur Caye oral tradition; 2) analyze the socio-cultural values of Selimbur Caye oral tradition. This research used qualitative descriptive method. Data collection was conducted using indepth interview, participatory observation, and documentation. The data was, then, analyzed using Miles and Huberman's interactive model of qualitative data analysis. The result of research showed that Selimbur Caye is a series of traditional expression, in the form of idioms containing life tenets. The traditional expressions consist of 6 advises and 6 prohibitions. Accordingly, the socio-cultural values contained in Selimbur Caye oral tradition are: 1) social care, 2) discussion and consensus; 3) honesty and justice; 4) responsibility; 5) personal rights respect; and 6) custom respect.
\end{abstract}

Keywords: Socio-Cultural Values; Selimbur Caye; Oral Traditio; Pasemah Ethnic.

\section{INTRODUCTION}

The rapid development of science, technology, information, and communication in global era has exerted distinctive effect on the nation-states in the world, particularly developing countries such as Indonesia. Globalization, supported by "new knowledge" and technology media has supported or impacted on the occurrence of cultural imperialism and cultural homogeneity (Hannerz. 1990:250; Sarikakis. 2001:81) [1] [2]. In addition, globalization also encourages the global communication, an uncountable network, which combines human beings into global mind (Abdullah. 2006:167) [3], leads to an awareness of world as a whole unity (Robertson. 1992:8) [4], and increase the distance that can be passed through by cultural effects in reaching all hemispheres (Boli \& Lechner. 2012:554) [5] . Hence, the world becomes narrower and borderless, as if it was a global village (Sariyatun. 2013:230) [6].

In such situation, the value exchange between nations runs quickly and dynamically. As a result, people are then faced with many value choices, thereby, also allowing obscurity and value shift, from local-national to global culture. As suggested by Mubah (2011: 255) [7], globalization tends to solidify the existence of values coming from developed countries and to remove traditional values in developing and poor countries. It is because developed country's values are considered as modern so they should be held tight, meanwhile, the developing country's values are considered as 
old-fa shioned so they should be abandoned. The local sources, former inspiring social action, are now shifting to global source (Abdullah. 2006:167) [3]. All of them will, then, lead to the lost of experience and understanding on local cultural diversity as the national identity (Sariyatun. 2014:3) [6].

However, globalization is an inevitable phenomenon. Self-closing from or warding off globalization is impossible. Otherwise, what should be done is to utilize globalization, to take positive values from globalization, and to refuse selectively the negative values that are hazardous (Ratna. 2014:47) [8]. Bachitiar Alam (1998:3) [9] states that globalization and cultural change should not be dealt by being an introvert. Otherwise, through understanding of how it is constructed in its discourse and praxis, for example, we can also utilize globalization process as the means to enrich our cultural plurality.

Dealing with such situation, a strong identity is an essential element needed (Sariyatun. 2014:1) [6]. To survive from the global culture influence, an individual or a community should have a strong identity. Therefore, exploring and living up the local wisdom vocabularies distributed in many areas are the wisest measures that can be taken. As Murden suggests (2001: 456) [10], local wisdom is the manifestation of ideology and the substance showing identity of each individual in a society. Furthermore, Mairah (2004: 202) argued that local wisdom can ward off the globalization effect proactively.

Substantially, local wisdom refers to cultural riches growing and developing in a community. It is also known and believed as an important element and as behavioral guidance - the existence of which can strengthen the social cohesion between community members (Haba. 2007:330; Sibrani. 2013:130) [11] [12]. Furthermore, Mestika Zed (2012:2) [13] explained that local wisdom contains moral values or messages that will direct its adherents to act accordingly. Sudikan (2013: 206) [14] says that local wisdom can also be defined as noble values contained in local cultural riches in the form of tradition, aphorism and life slogan. In other words, cultural values are functioned as parameter and measurement in determining if something is good or bad, valuable or valueless, allowed or not allowed, etc. In addition, local wisdom, as an ideology, can also arise a resistance against global ideology (Mulyana. 2009:2) [15].

In Indonesia, local wisdom can be found in nearly all cultural variants existing, including in oral culture (also called as folklore). Folklore, according to Danandjaja (2007:2) [16] is a part of a certain communities' culture which is distributed and maintained hereditarily between any collectives, traditionally in different versions (either in spoken or one accompanied with gesture or reminder). According to Bascom, folklore has four functions: 1) as projective system - as the reflector of a collective imagination; 2) as the means of ratifying cultural institutions and organizations; 3) as pedagogical device; and 4) as a compelling and supervising medium to ensure that the societal norms are always be obeyed by its collective members (Sibrani, 2013: 3) [17].

In relation to value system, Sibrani (2013: 17) [17] argued that folklore contains cultural value that can be utilized as the source of education. Cultural value contained in folklore genre is the messages used as a source of knowledge or education for the next generation. Furthermore, Danandjaja (2015: 80-81) [19] suggested that to find out order of conduct, folklore is one of most valid materials.

In the context of Pasemah society in Bengkulu, Selimbur Caye oral tradition is a manifestation of local culture containing life tenets, particularly on how an individual, as the member of society, positions him/her self in social intercourse (Interview with 
respondent A. 6/8/2016). In other words, Selimbur Caye contains social values, about what may and what may not be done, or what the Pasemah people call "anjuran" (advice) and "pantangan" (prohibition), (Interview with respondent C. 2/8/2016). Thus, it can be concluded that Selimbur Caye occupies the important function in Pasemah Bengkulu community as the guidance of behaving for the community.

Regarding folklore categorization proposed by James Danandjaja, Selimbur Caye belongs to oral folklore or oral tradition belonging to traditional expression. Moreover, Cervantes in Dandandjaya (2007: 28) [16] said that traditional expression or proverb is the short sentence abstracted from a long experience. Therefore, Selimbur Caye, as an oral tradition, is considered as the valuable cultural heritage playing an important part in the attempt to establish concord in social life-particularly for Pasemah community in Bengkulu.

Based on the elucidation above, the author thinks that it is very important to conduct a research regarding Selimbur Caye oral tradition, particularly because of its position as a local wisdom. However, because of some limitations, this research focused on two points only: 1) the description of the content and meaning of Selimbur Caye oral tradition; and 2) socio-cultural values analysis of Selimbur Caye oral tradition.

\section{RESEARCH METHOD}

This research belongs to a descriptive qualitative research, the one used to find out knowledge as wide as possible about the subject of research at certain moment (Mukhtar, 2013: 10) [19]. The subject of this research is oral tradition text (Selimbur Caye) distributed in Pasemah community in Bengkulu. The text of Selimbur Caye oral tradition is a series of traditional expression in the form of metaphors containing moral tenets. Totally, there are twelve expressions of Selimbur Caye: six advices and six prohibitions.

The data collection process, especially on the matter of Selimbur Caye's content and meaning, was conducted using in-depth interview as the main technique, (Patton. 2006:1; Sutopo. 2006:68) [20]. The interviews were conducted with a number of informants selected based on certain criteria corresponding to substance, characteristic, and objective of research. In this case, the selected informants are those who understand Selimbur Caye oral tradition well, particularly, customary leaders. Another technique used was document study (document of custom) focused on both official documents such as customary meeting decision and unofficial documents which are stored by individuals.

The data collected are analyzed using Milles and Huberman's qualitative data analysis which consist of three stages: 1) data reduction, 2) data display, and 3) conclusion drawing, (Miles and Huberman, 2014: 6) [21].

\section{RESULT AND DISCUSSION}

\section{Description of Selimbur Caye}

As mentioned, Selimbur Caye oral tradition is a series of traditional expressions containing advices on how an individual or a community behaves in social life. The 
content of Selimbur Caye, generally, according to Duriani, can be categorized into two: "anjuran" (advice) and "pantangan" (prohibition), (Interview with Respondent A, 6/8/2016). Furthermore, Agus Setiyanto explains that the advice expression is, indirectly, an ideal or expectation, while prohibition expression is a threat or strict warning, that will affect adversely those who breaks it (Interview with respondent B, 28/3/2017).

Based on the result of interview conducted with the customary leaders of Pasemah Bengkulu community, particularly in Kedurang and Padang Guci areas, the content and the meaning of those two expressions can be described as follows:

\section{SIX ADVICES (LIFE PHILOSOPHY)}

1) Seanak bujang seanak gadis: is a life philosophy pertaining collective responsibility of all community members in educating children. With the principle of seanak bujang seanak gadis (your child is mine, and my child is yours as well). Thus, all children in the village should must be considered as everyone's children so when a child conducts mistakes or breaks norms, it is an obligation for everyone to reprimand or to advise.

2) Sepincang sepejalanan: is a principle pertaining to how to treat the comrades in arms. The closes example of the principle manifestation is when one person in a group has a problem (in struggle for something) it means that the problem must be solved together (sepincang) as the members of the group are considered family. In a well-known Indonesian's proverb, the principle has similar meaning with the expression "senasib sepenanggungan" or "berat sama dipikul ringan sama dijinjing".

3) Seghepat seghendi: is the principle concerning attitude towards living within society, particularly in discussion. In a discussion arguments and perspectives are common things which often triggered debates. Relatedly, in the context of seghepat seghendi principle, an individual who hold tight onto it must put aside his/her self-ego and willingly accept whatever the collective decision taken.

4) Seganti setungguan: it is a philoshopy that, substantially, has similar meaning with the principle of sepincang sepejalanan (concerning on the matter of solidarity). The word "seganti" literally means "take turns". It can be interpreted that everything related to the public life must be shared together. Meanwhile, the word "setungguan" literally means "waiting for each other", which take a manifestation in action to help each other. In other words, the expression has the meaning that one's problem is everyone's problem in the community.

5) Janji nunggu kate betaruh: the philosophy of janji nunggu kate betaruh is a principle concerning responsibility for duty or promise (An individual should keep his promise). Meanwhile, the expression "kate betaruh" concerns on the responsibility for words said. Words that has been said, for pasemah people, is a symbolization of a bet, so every word said is a debt that must be paid. The function of such principle is as a reminder that when a person has said his words, promises, or vows they are waited to be paid or realized.

6) Ndepat mbalik, ngutang mbayar, serame beghagih: this philosophy is basically consists of three principles. Ndepat mbalik means that if one finds others' belonging, it is an obligation for the founder to give it back to the owner 
whatever it cost. Meanwhile, the expression "ngutang mbayar" is related to the matter of debts and receivables principle, in which a person who owed something from others must pay it in the same amount as it was taken. In a social life, debts and receivables is a common activity. However, everyone should realize that this kind of matter has really high level of sensitivity that is potential to trigger a conflict if it is not treated accordingly. The third principle is serame beghagih which concerns on the basic principle of co-operation. In any context, every party in a co-operative relationship must act fairly. For example, in a business activity, if there is a certain amount of profit got from it, then, it must be shared fairly as what has been agreed before by the parties involved.

\section{SIX PROHIBITIONS}

1) Jangan nube ulu mandian: this expression contains prohibition for the members of the community from doing something harmful to others. In living within society, every individual is given a freedom to make a living in any ways they fit, but it does not mean that they may act "freely". They should consider whether or not their attempts are harmful to others. Hence, the imperative expression "jangan nube ulu mandian" which literally means "Don't poison the bathing place" (certain persons in pasemah community usually poison the river to ease them when they are fishing, whereas, river is also the place used by most of the community members to take a bath) fit perfectly with the idea of principle mentioned before.

2) Jangan nutuh dahan peninggighan: the phrase "dahan peninggighan" is related to two things: others' livelihood source and leadership in a community. In the matter of others' livelihood source, an individual is prohibited from disturbing it, even less, damaging it. Meanwhile, regarding the issue of leadership, an individual must appreciate, respect, and not overthrow his power for the sake of self-interest. Therefore, it can be concluded that the expression "jangan nutuh dahan peninggighan" means every individual in the community is prohibited from bothering others, have to respect each other, and must be loyal to their leader.

3) Jangan maraska batu keluagh: is the prohibition for every community member from wagging others' "dirty" secret. "Batu" (Stone) in this expression symbolized bad thing (others' disgrace) that must not be thrown (maraska) to the other people (keluagh). In other words, this expression guide the people to save others' face whatever it cost because one's ignominy is also the others.

4) Jangan menghebe pelaluan: is prohibition forbidding any action that harm others. In this expression, pelaluan (road) symbolized people's interest as the road is utilized by the public.

5) Jangan nyeghuti jalan kayik: jalan kayik here is a metaphor for something very clean, (in the contexts of blood relation or kinship). Those still having kinship are prohibited from getting married or having date. Such relationships are considered as nyeghuti (contaminating), a prohibited deed in Pasemah community.

6) Jangan ngunggung pelidian: the word "ngunggung" means carrying off something. Meanwhile, pelidian means small woods (sometimes made of palm leaf rib), greased with pulut (a kind of local natural glue used to catch birds in 
the forest). In specific, the word "pelidian" is a metaphor symbolizing responsibility or duty. Hence, the expression "jangan ngunggung pelidian" is interpreted as prohibiting the society members from irresponsible conducts.

\section{Socio-cultural Values of Selimbur Caye}

Based on the meaning of each expression in selimbur caye oral tradition, it can be concluded that the selimbur caye oral tradition contains socio-cultural values as follows:

Firstly, social care or caring about fellow human beings. It is an attitude regarding human position as social creatures that cannot fulfill their own need, and for that reason, they should pay attention to each other, and help each other. In the context of Pasemah people in Bengkulu, social care is a fundamental principle which is held tight. Such principle is reflected in selimbur caye oral tradition as their life philosophy. The social care value can be found in seanak bujang seanak gadis (caring about children or young generation), sepincang sepejalanan and seganti setungguan expressions (caring about comrades in arm) .

Secondly, socio-cultural value contain in selimbur caye is democratic value (musyawarah \& mufakat). Regarding this value, it is something important to be taken into account. Accordingly, Pasemah people in Bengkulu uphold such value with all their might. The representation of the effort can be seen in one of expression in selimbur caye (seghepat seghendi), pertaining one's acceptance toward consensus. It is like what Yasman suggests that seghepat seghendi is an expression concerning consensus, in which we are told or advised to receive mutual agreement openly without compelling personal interest (Interview with Respondent C, 10/8/2016).

Thirdly, upholding honesty and justice. Being honest and fair is a key to the realization of social harmony. In selimbur caye, advice concerning honesty and justice contained in the expression ndepat mbalik, ngutang mbayar, serame beghagih. The meaning of this expression is very clear that when we found something belonging to others, we should return it to the owner; if we have loan, we should repay; and when we have a goods or other valuable things together, we should treat it justly.

Fourthly, responsibility. In simple way, we can say that responsibility is the ability to respond or to answer. It means that responsibility is oriented to otherspaying attention, and responding actively to what they want. Responsibility is emphasized on the positive obligation to protect each other. It is an attitude of needing each other, not ignoring other in difficult times. Thus, responsibility is a must for everyone. In other words, every individual has their own responsibilitiesto God, to others, or to themselves.

In selimbur caye, there are three forms of responsibility mandated. First, the responsibility to advice each other or remind each other (see the expression seanak bujang seanak gadis). Second, the responsibility on words and promise (see the expression janji nunggu kate betaruh). The last, responsibility regarding work (see the expression jangan ngunggung pelidian).

The fifth, upholding or respecting others' personal rights. Respect means showing appreciation to others' self-esteem or other thing besides ourselves. Having high respect to others' personal rights, an individual will not conduct a attempt that can harm others. There are some expressions in selimbur caye oral traditions 
containing advice to respect or to uphold others personal rights: 1) jangan nube ulu mandian and jangan nutuh dahan peninggighan (respecting others' right in having business/effort); 2) jangan menghebe pelaluan (concerning others' right to public facilities); 3) jangan ngunggung pelidian (not escaping from responsibility to others); and (4) jangan maraska batu keluagh (prohibition to wag others' "dirty" secret).

Sixth, respecting the prevailing customs. Just like respect to others' personal right, the prevailing customs in a society needs to be respected as well. Through high custom respect, the loyalty can be realized. Concerning this issue, the tenet contained in the expression jangan nyeghuti jalan kayik (the prohibition for Pasemah community from getting married to those having blood relation or kinship).

Considering the elaboration above, it can be concluded that selimbur caye oral tradition is replete with socio-cultural values, the existence of which is very essential in global era today. By understanding and implementing those values, there will be no more problems occurring amid the society. For more information about sociocultural values contained in selimbur caye oral tradition, see the table below.

TABLE I. SOCIO-CULTURAL VALUES OF SELIMBUR CAYE ORAL TRADITION:

\begin{tabular}{|c|c|c|}
\hline Value Item & Relevant Expression & Value Description \\
\hline - Social care & $\begin{array}{l}\text { - Seanak bujang seanak } \\
\text { gadis. } \\
\text { - Sepincang sepejalanan. } \\
\text { - Seganti setungguan. }\end{array}$ & $\begin{array}{l}\text { Taking care of children } \\
\text { collectively as the next } \\
\text { generation. } \\
\text { - Helping comrades in arms. } \\
\text { - Not attempting treason to } \\
\text { comrades. }\end{array}$ \\
\hline $\begin{array}{l}\text { - Democracy } \\
\text { (discussion and } \\
\text { consensus) }\end{array}$ & - Seghepat seghendi. & $\begin{array}{l}\text { - Being supportive in discussion } \\
\text { - Accepting and respecting the } \\
\text { result of discussion. }\end{array}$ \\
\hline - Honesty and justice. & $\begin{array}{l}\text { - Ndepat mbalik, ngutang } \\
\text { mbayar, serame beghagih. }\end{array}$ & $\begin{array}{l}\text { - Not taking something which is } \\
\text { not our right. } \\
\text { - Not doing fraud. }\end{array}$ \\
\hline - Responsibility. & $\begin{array}{l}\text { - Seanak bujang seanak } \\
\text { gadis. } \\
\text { - Janji nunggu kate } \\
\text { betaruh. } \\
\text { - Jangan ngunggung } \\
\text { pelidian. }\end{array}$ & $\begin{array}{l}\text { Taking care of children } \\
\text { collectively as the next } \\
\text { generation. } \\
\text { - Keeping promise. } \\
\text { - } \text { Performing obligation well. } \\
\text { - } \text { Not escaping from } \\
\text { responsibility. } \\
\end{array}$ \\
\hline $\begin{array}{l}\text { - Personal rights } \\
\text { respect. }\end{array}$ & $\begin{array}{l}\text { - Jangan nube ulu mandian. } \\
\text { - Jangan nutuh dahan } \\
\text { peninggighan. } \\
\text { - Jangan menghebe } \\
\text { pelaluan. } \\
\text { - Jangan ngunggung } \\
\text { pelidian. } \\
\text { - Jangan maraska batu } \\
\text { keluagh. }\end{array}$ & $\begin{array}{l}\text { - Not doing anything harmful to } \\
\text { others. } \\
\text { - Not damaging public facilities. } \\
\text { - Not escaping from } \\
\text { responsibility. }\end{array}$ \\
\hline - Custom respect. & $\begin{array}{l}\text { - Jangan nyeghuti jalan } \\
\text { kayik. }\end{array}$ & $\begin{array}{l}\text { - Not getting married to those } \\
\text { having blood relation. }\end{array}$ \\
\hline
\end{tabular}




\section{CONCLUSION}

Selimbur caye is a type of oral folklore or oral tradition in the form of traditional expression or proverb containing life ideology and prohibition. Considering the result of analysis conducted, it can be concluded that selimbur caye oral tradition is replete with socio-cultural values. Some social-cultural values that can be taken from selimbur caye oral tradition are as follows: 1) social care, 2) discussion and consensus; 3) honesty and justice; 4) responsibility; 5) personal rights respect; and 6) custom respect.

Furthermore, introducing Selimbur Caye oral tradition to the young generation as the next generation is considered as very important, particularly in the attempt to preserve it as the nation's cultural heritages. Despite the "traditional" characteristics, social-cultural values contained in Selimbur Caye oral tradition is still relevant to Indonesian condition today or even very desirable indeed.

\section{REFERENCES}

[1] Hannerz, U. 1990. Cultural Complexity: Studies in the Social Organization of Meaning. New York: Columbia University Press.

[2] Sarikakis, K. 2005. Legitimating Domination: Notes of the Changing Faces of Cultural Imperialism. In Hamm, B and Smandich, R (ed). Cultural Imperialism: Essays on the Political Economy and Cultural Domination. Canada: Broadview Press Ltd.

[3] Abdullah, I. 2006. Konstruksi dan Reproduksi Kebudayaan. Yogyakarta: Pustaka Pelajar.

[4] Robertson, R. 1992. Globalization: Social Theory and Global Culture. London: SAGE.

[5] Boli, J and Lechner, F. J. 2012. Teori Globalisasi. In Bryan S. Turner (ed). Teori Sosial: Dari Klasik Sampai Postmodern. Transleted by E. Setiyawati A \& Roh Shufiyati. Yogyakarta: Pustaka Pelajar.

[6] Sariyatun. "Redefinisi Nilai-Nilai Filosofis Batik Klasik Melalui Pembelajaran IPS untuk Ketahanan Budaya Lokal" Disampaikan dalam Pidato Pengukuhan Guru Besar Pendidikan IPS FKIP-UNS. Solo, 2 Desember 2014.

[7] Mubah, A. S. "Revitalisasi Identitas Kultural Indonesia di Tengah Homogenitas Global" in Global \& Strategis (Special Edition). December 2011. Hlm. 251-260.

[8] Ratna, N. K. 2015. Peranan Karya Sastra, Seni, dan Budaya dalam Pendidikan Karakter. Yogyakarta: Pustaka Pelajar.

[9] Alam, B. "Globalisasi dan Perubahan Budaya: Perspektif Teori Kebudayaan" in Antropologi Indonesia. No. 54 Th. 2008. Hlm. 1-11

[10] Murden, S. 2001. Culture and World Affair. In Baylis, J and Smith, S (ed). The Globalization of Word Politics: An Introduction to International Relation. New York: Oxford University Press.

[11]Haba, J. 2007. “Analisis SWOT Kearifan Lokal dalam Resolusi Konflik” dalam Alpha Amirrachman (ed). Revitalisasi Kearifan Lokal: Studi Resolusi Konflik di Kalimantan Barat, Maluku, dan Poso. Jakarta: ICIP.

[12] Sibrani, R. 2013. "Revitalisasi Folklor sebagai Sumber Kearifan Lokal" in Suwardi Endaswara, dkk (ed). Folklor and Folklife dalam Kehidupan Dunia Modern: Kesatuan dan Keberagaman. Yogyakarta: Ombak.

[13]Zed, M. "Peran Sejarah dalam Menggali Kearifan Lokal sebagai Warisan Budaya Bnagsa" Paper Presented in National Seminar of IKAHIMSI. Padang, 12 April 2012.

[14] Sudikan, S. Y. 2013. "Kearifan Lokal dalam Tradisi Lisan Nusantara" in Suwardi Endaswara (ed). Folklor Nusantara: Hakikat, Bentuk dan Fungsi. Yogyakarta: Ombak.

[15] Mulyana, A. "Mengembangkan Kearifan Lokal dalam Pembelajaran Sejarah" Paper Presented in International Conferences “ Mengembangkan Social Skill dalam Pembelajaran IPS di Sekolah. Bandung, 29 January 2009. 
[16]Danandjaja, J. 2007. Foklor Indonesia: Ilmu Gosip, Dongeng, dan Lain-Lain. Jakarta: Grafiti.

[17] Sibrani, R. 2013. "Folklor Sebagai Media dan Sumber Pendidikan: Sebuah Ancangan Kurikulum dalam Pembentukan Karakter Siswa Berbasis Nilai Budaya Batak Toba" dalam Suwardi Endaswara (ed). Folklor Nusantara: Hakikat, Bentuk dan Fungsi. Yogyakarta: Ombak.

[18] Danandajaja, J. 2015. "Folklor dan Pembangunan Kalimantan Tengah: Merekonstruksi Nilai Budaya Orang Dayak Ngaju dan Ot Danum Melalui Cerita Rakyat Meraka" dalam Pudntia MPSS (ed). Metodologi Kajian Tradisi Lisan. Jakarta: Obor.

[19] Mukhtar. 2013. Metode Praktis Penelitian Deskriptif Kualitatif. Jakarta: Referensi.

[20] Sutopo, H. B. 2006. Metodologi Penelitian Kualitatif: Dasar Teori dan Terapannya dalam Penelitian. Surakarta: Universitas Sebelas Maret.

[21] Milles, M. B \& Huberman, A. M. 2014. Analisis Data Kualitatif. Transleted by Tjetjep Rohendi Rohidi. Jakarta: UI Press.

[22] Bogdan, R. C. \& Biklen, S. K. 1982. Qualitative Researh for Education: An Introduction to Theory and Methods. Boston: Allyn and Bacon, Inc.

[23] Sariyatun. "Pengembangan Model Pendidikan Nilai-Nilai Budaya di SMP Berbasis Tradisi Seni Batik Klasik di Surakarta" dalam PARAMITA: Jurnal Sejarah dan Pembelajaran Sejarah. Vol. 23 No. 2. Juli-2013. Hlm. 230-241.

\section{List of Informant:}

\begin{tabular}{|c|c|c|c|}
\hline No & Name & $\begin{array}{c}\text { Occupation/Position/ } \\
\text { Age }\end{array}$ & Place and date of Interview \\
\hline 1. & $\begin{array}{c}\text { Durlani } \\
\text { (Respondent A) }\end{array}$ & $\begin{array}{l}\text { Retired Civil Servant / } \\
\text { Custom Head } / 75 \text { years. }\end{array}$ & $\begin{array}{l}\text { Pagar Bunga Village,. Kedurang Sub } \\
\text { District, Bengkulu Selatan, } 6 \text { August } \\
2016 .\end{array}$ \\
\hline 2. & $\begin{array}{l}\text { Dr. Agus Setiyanto } \\
\text { (Respondent B) }\end{array}$ & $\begin{array}{c}\text { Civil } \\
\text { Servant/Historicist/ } 59 \\
\text { years. }\end{array}$ & $\begin{array}{l}\text { Library of Universitas } \\
\text { Bengkulu, } 28 \text { March 2017. }\end{array}$ \\
\hline 3. & $\begin{array}{c}\text { Sumardi } \\
\text { (Respondent C) }\end{array}$ & $\begin{array}{c}\text { Farmer/ Jurai Tue/ } 70 \\
\text { years }\end{array}$ & $\begin{array}{l}\text { Durian Sebatang Village, Kedurang } \\
\text { Sub District, Bengkulu Selatan, } 2 \\
\text { August } 2016 .\end{array}$ \\
\hline 4. & $\begin{array}{c}\text { Yasman } \\
\text { (Respondent D) }\end{array}$ & $\begin{array}{l}\text { Retired Civil Servant / } \\
\text { Apit Jurail } 71 \text { year }\end{array}$ & $\begin{array}{l}\text { Durian Sebatang Village, Sub District, } \\
\text { Bengkulu Selatan, } 12 \text { August } 2016 .\end{array}$ \\
\hline 5. & $\begin{array}{c}\text { Imintri } \\
\text { (Respondent E) }\end{array}$ & $\begin{array}{l}\text { Farmers/ Society } \\
\text { Leader/ } 58 \text { years }\end{array}$ & $\begin{array}{l}\text { Durian Sebatang Village, Sub District, } \\
\text { Bengkulu Selatan, } 6 \text { April } 2017 .\end{array}$ \\
\hline
\end{tabular}

